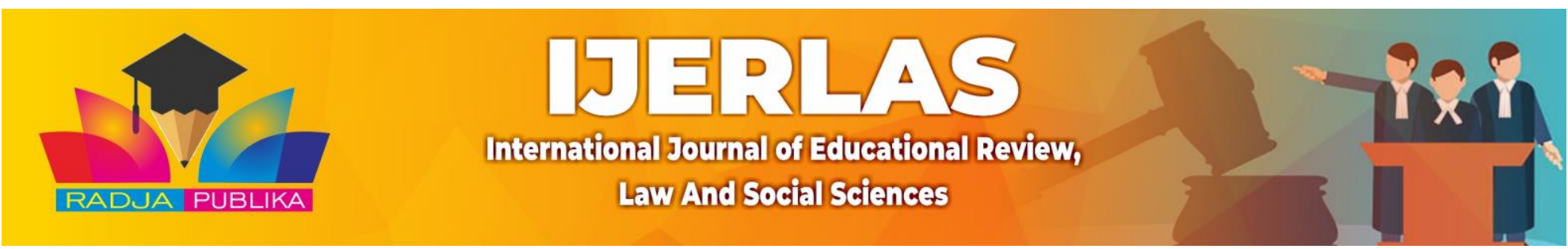

\title{
DETERMINANT MODEL OF CORPORATE DISCLOSURE SOCIAL RESPONSIBILITY
}

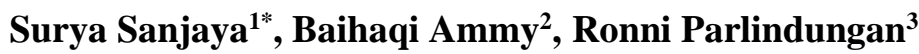 \\ ${ }^{1,2,3}$ Faculty of Economics and Business, Universitas Muhammadiyah Sumatera Utara \\ E-mail: ${ }^{1)}$ suryasanjaya@umsu.ac.id * \\ 2) baihaqiammy@umsu.ac.id, ${ }^{3)}$ roniparlinsipahutar@gmail.com
}

\begin{abstract}
This research aims to find out the Effect of Company Size, Board of Commissioners Size, and Profitability on Corporate Social Responsibility Listed on the Indonesia Stock Exchange for the Period 2014-2018. This research approach uses an associative research approach. The method of data collection is done by means of data documentation sourced from the annual report of the Indonesia Stock Exchange. Based on the collection of samples conducted using the check list according to criteria, obtained the number of research samples as many as 6 companies from 15 populations. Research samples during the period 2014-2018 and data analysis techniques in this study are descriptive statistics, classical assumption tests that include normality tests, multicollinearity tests, and heteroskedity tests, multiple linear regression analysis, hypothesis testing which includes $t$ test, $f$ test and coefficient of determination. The results showed that the Size of the Company had a positive but insignificant effect on Corporate Social Responsibility Disclosure, the Size of the Board of Commissioners had a positive but insignificant effect on the disclosure of Corporate Social Responsibility, and Profitability had a positive but insignificant effect on the disclosure of Corporate Social Responsibility on Automotive companies listed on the Indonesia Stock Exchange for the period 2014-2018.

Keywords: Company Size, Board Size, Profitability, and Disclosure of Corporate Social Responsibility.
\end{abstract}

\section{INTRODUCTION}

Disclosure of Corporate Social Responsibility has been stated in Law No. 40 of 2007 article 74 that CSR is a manifestation of corporate responsibility as outlined in the company's annual report. And in the law, every company is obliged to carry out CSR activities in order to maintain the environment so that it is maintained and maintained from the business activities that have been carried out. Companies not only have economic and legal obligations but also have obligations to other interested parties.

According to (Putri \& Gunawan, 2018)of several factors that influence companies to disclose CSR, one of which is the size of the Board of Commissioners, within the company the board of commissioners has a fairly strong management authority, where the authority of the board of commissioners is used to influence people within the company to carry out their social responsibilities. For this reason, a large board of commissioners is needed, so that the company can also carry out its social responsibilities well. In addition to carrying out social responsibility, companies are also required to disclose it through financial statements. Because the company's financial statements can be used by companies to provide confidence for stakeholders and shareholders that the company has social responsibility and as a basis for decision making.

Not only the size of the board of commissioners, in making investment decisions. Investors often see the size of the company and make an assessment of the company's financial performance; company size is an estimator variable that is widely used to explain the variance of disclosure in the company's annual report. This is in line with agency theory where large companies that have greater agency costs will disclose wider information to reduce agency costs. In addition, large companies 
are issuers that are widely highlighted, greater disclosure is a reduction in political costs as a form of corporate social responsibility.(Retired, 2019).

Another company characteristic that is used as a measure in CSR disclosure is the profitability ratio, which is the company's ability to generate profits at certain levels of sales, assets and share capital. Companies that generate high profits will find it easier to contribute to the social environment around the company(Susilowati et al., 2018). The object of the research was 15 automotive companies listed on the Indonesia Stock Exchange in the 2014-2018 period, and researchers took 6 samples of companies that will be used as data sources in describing the phenomena that occur, as follows:

Table 1 Financial Data of Automotive Sector Manufacturing Companies on the IDX (in billions of 2014-2018)

\begin{tabular}{|c|c|c|c|c|c|}
\hline Company name & Year & $\begin{array}{l}\text { Company } \\
\text { Size } \\
\text { (Total Assets) }\end{array}$ & $\begin{array}{c}\text { Board of } \\
\text { Commissioners } \\
\text { Size } \\
\text { (Number of } \\
\text { Commissioners) }\end{array}$ & $\begin{array}{l}\text { Profitability } \\
\text { (ROA) }\end{array}$ & $\begin{array}{c}\text { Corporate } \\
\text { Social } \\
\text { Responsibility } \\
\text { (Cost CSRD) }\end{array}$ \\
\hline $\begin{array}{l}\text { PT. Astra } \\
\text { International,Tbk }\end{array}$ & $\begin{array}{l}2014 \\
2015 \\
2016 \\
2017 \\
2018 \\
\end{array}$ & $\begin{array}{r}236.029000 \\
245.435 .000 \\
261.855 .000 \\
295,646,000 \\
333,325,000\end{array}$ & $\begin{array}{l}11 \\
11 \\
12 \\
12 \\
10\end{array}$ & $\begin{array}{l}9.37 \\
6.36 \\
6.99 \\
7.84 \\
6.46 \\
\end{array}$ & $\begin{array}{r}726,382,000 \\
342,627,000 \\
377,594,000 \\
1.093 .500 .000 \\
1,053,380,000\end{array}$ \\
\hline $\begin{array}{l}\text { PT. Astra } \\
\text { Otoparts, Tbk }\end{array}$ & $\begin{array}{l}2014 \\
2015 \\
2016 \\
2017 \\
2018 \\
\end{array}$ & $\begin{array}{l}14,380,926 \\
14,339,110 \\
14,612,274 \\
16,762,309 \\
15,890,613 \\
\end{array}$ & $\begin{array}{c}10 \\
8 \\
8 \\
8 \\
8 \\
\end{array}$ & $\begin{array}{l}6.65 \\
2.25 \\
3.31 \\
3.71 \\
2.81 \\
\end{array}$ & $\begin{array}{r}1,648,193,992 \\
254.592 .250 \\
576,602,850 \\
449,368,000 \\
1,287,374,750 \\
\end{array}$ \\
\hline $\begin{array}{l}\text { PT. Single } \\
\text { Elephant, Tbk }\end{array}$ & $\begin{array}{l}2014 \\
2015 \\
2016 \\
2017 \\
2018 \\
\end{array}$ & $\begin{array}{l}16,042,897 \\
17,509,505 \\
18,697,779 \\
18,191.176 \\
19,711,819 \\
\end{array}$ & $\begin{array}{c}6 \\
6 \\
9 \\
8 \\
10\end{array}$ & $\begin{array}{c}1.68 \\
-1.79 \\
3.35 \\
0.25 \\
-1.16 \\
\end{array}$ & $\begin{array}{l}10.007 .000 \\
11.005 .000 \\
12.008 .000 \\
12,000,000 \\
12,000,000 \\
\end{array}$ \\
\hline $\begin{array}{l}\text { PT. Mitra } \\
\text { Pinasthika } \\
\text { Mustika, Tbk }\end{array}$ & $\begin{array}{l}2014 \\
2015 \\
2016 \\
2017 \\
2018\end{array}$ & $\begin{array}{l}13,950,177 \\
14,480,403 \\
14.926 .225 \\
10,175,997 \\
12,544,059\end{array}$ & $\begin{array}{l}6 \\
6 \\
6 \\
6 \\
5\end{array}$ & $\begin{array}{c}3.63 \\
2.13 \\
2.75 \\
3.91 \\
33.52\end{array}$ & $\begin{array}{r}1,602,000,000 \\
736,000,000 \\
326,705,000 \\
110,315,500 \\
1,981,354,435\end{array}$ \\
\hline $\begin{array}{l}\text { PT. Multistrada } \\
\text { Directions Sarana, } \\
\text { Tbk }\end{array}$ & $\begin{array}{l}2014 \\
2015 \\
2016 \\
2017 \\
2018 \\
\end{array}$ & $\begin{array}{l}7,775,033 \\
8,771,177 \\
8,192,537 \\
8,909,285 \\
9,923,493 \\
\end{array}$ & $\begin{array}{l}5 \\
5 \\
5 \\
5 \\
7\end{array}$ & $\begin{array}{c}0.08 \\
-4.49 \\
-1.10 \\
-1.23 \\
0.09 \\
\end{array}$ & $\begin{array}{r}1,146,516,000 \\
818,940,000 \\
846,238,000 \\
1,364,900,000 \\
1,364,901,000 \\
\end{array}$ \\
\hline $\begin{array}{l}\text { PT. } \\
\text { Congratulations } \\
\text { Perfect, Tbk }\end{array}$ & $\begin{array}{l}2014 \\
2015 \\
2016 \\
2017 \\
2018 \\
\end{array}$ & $\begin{array}{l}1,749,395 \\
2.220 .108 \\
2,254,740 \\
2,443,341 \\
2,793,575 \\
\end{array}$ & $\begin{array}{l}3 \\
3 \\
3 \\
2 \\
2 \\
\end{array}$ & $\begin{array}{c}24.09 \\
20.78 \\
22.27 \\
22.73 \\
7.23 \\
\end{array}$ & $\begin{array}{l}141,000,000 \\
144,000,000 \\
269,983,504 \\
399,185,710 \\
982,709,774\end{array}$ \\
\hline
\end{tabular}

Based on table 1.1 above, it can be seen that the company size at PT. Astra International, Tbk in the observation year 2014 to 2018 tends to increase and is not followed by CSR disclosure which tends to be lower. This can be seen from 2014-2015 and 2017-2018. For this reason, this is not in line with theory (Putri \& Gunawan, 2018) which states that the larger the company, the wider the 


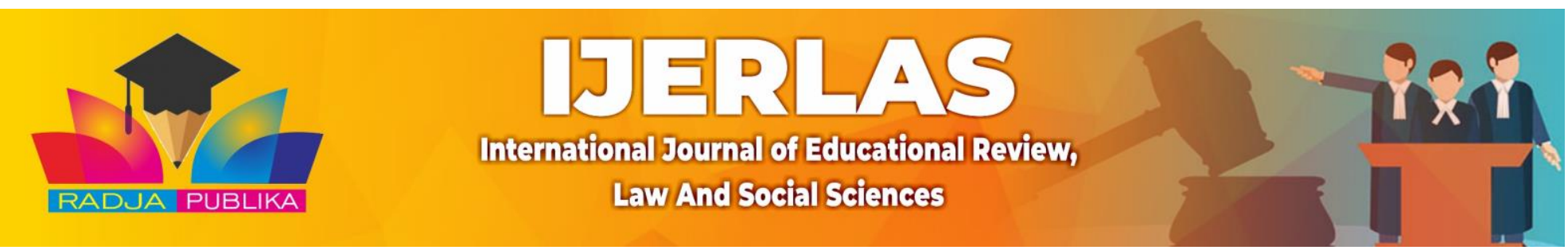

CSR disclosure will be. Due to the operating activities of large companies, the pressure obtained by large companies is to have more information than small companies, so that there will be more items that must be disclosed in the financial statements, including social disclosures.

At the company PT. Astra Otoparts, Tbk can be seen in table 1.1 for Company Size in the observation year 2014 to 2018 which tends to increase and is not followed by CSR disclosures which tend to be lower in social activities. This can be seen from 2016-2017, while in 2017-2018 it experienced a decline and was not followed by CSR disclosures which tended to be higher in social activities. What happened both between 2016-2017 and 2017-2018 is not in line with theory(Putri \& Gunawan, 2018)which states that the larger the company, the wider the CSR disclosure will be. Due to the operating activities of large companies, the pressure obtained by large companies is to have more information than small companies, so that there will be more items that must be disclosed in the financial statements, including social disclosures.

Profitability at the company PT. Astra Otoparts, Tbk as shown in table 1.1 has decreased from 2014 to 2018, although it has increased and is not followed by CSR disclosure which tends to decrease for its social responsibility, this can be seen in 2016-2017. Whereas in 2017-2018 experienced the opposite, profitability decreased and was not followed by CSR disclosure which tended to increase for social responsibility. What happened both between 2016-2017 and 2017-2018 is not in line with theory (Fahmi, 2019) which states that with high profits, management will make extensive disclosures by providing information on social and environmental disclosures because it greatly affects the company's position and the compensation or risk received.

Profitability at the company PT. Gajah Tunggal, Tbk as shown in table 1.1 experienced a decline from 2014-2018, although it decreased. profitability is not followed by CSR disclosure which tends to increase for its social responsibility, this can be seen in 2014-2015 which is not in line with the theory(Fahmi, 2019) which states that with high profits, management will make extensive disclosures by providing information on social and environmental disclosures because it greatly affects the company's position and the compensation or risk received.

At the company PT. Mitra Pinasthika Mustika, Tbk which can be seen in table 1.1 Company size has increased but not followed by CSR disclosure which tends to decrease. This is clearly seen in the 2015-2016 observation year which is not in line with theory(Putri \& Gunawan, 2018)which states that the larger the company, the wider the CSR disclosure will be. Due to the operating activities of large companies, the pressure obtained by large companies is to have more information than small companies, so that there will be more items that must be disclosed in the financial statements, including social disclosures.

The size of the board of commissioners at the company PT. Mitra Pinasthika Mustika Tbk, which is shown in table 1.1, experienced a reduction in the number of commissioners from 20142018, although it experienced a slight reduction in the number of commissioners, which was not followed by CSR disclosures which tended to increase. This is clearly seen in the 2017-2018 observation year which is not in line with theory(Chen, 2019) which states that the larger the size of the board of commissioners in the company, the easier it will be to monitor the tasks of management in carrying out business activities and make management bigger in disclosing the company's CSR implementation.

Profitability of the company that looks PT. Mitra Pinasthika Mustika, Tbk in table 1.1 has decreased from 2014 to 2018, and is followed by CSR disclosure which tends to increase. This is clearly seen in the 2014-2015 observation year. However, the opposite happened in 2015-2017 which increased but was not followed by CSR disclosure which tended to decrease. For this reason, what happened in 2014-2015 or in 2015-2017 is not in line with theory(Fahmi, 2019) which states that with high profits, management will make extensive disclosures by providing information on social and environmental disclosures because it greatly affects the company's position and the compensation or risk received. 
At the company PT. Multistrada Arah Sarana, Tbk which can be seen in table 1.1 Company size tends to increase from 2014 to 2018 , and is followed by CSR disclosure which tends to decrease. This is clearly seen in the 2014-2015 observation year, while in 2015-2016 the opposite happened, it decreased but was not followed by CSR disclosure which tended to increase. things that happened in 2014-2015 or in 2015-2016 are things that are not in line with theory(Putri \& Gunawan, 2018)which states that the larger the company, the wider the CSR disclosure will be. Due to the operating activities of large companies, the pressure obtained by large companies is to have more information than small companies, so that there will be more items that must be disclosed in the financial statements, including social disclosures.

Profitability at the company PT. Multistrada Arah Sarana, Tbk in table 1.1 decreased from 2014 to 2018, and was followed by CSR disclosure which also increased from 2014 to 2018 . This is clearly seen in the 2015-2016 and 2016-2017 observation years which did not in line with theory(Fahmi, 2019) states that with high profits, management will make extensive disclosures by providing information on social and environmental disclosures because it greatly affects the company's position and the compensation or risk received.

Profitability at the company PT. Selamat Sempurna, Tbk as shown in table 1.1 experienced a decrease from 2014 to 2018, but although the decline in profitability was not followed by CSR disclosure which tended to increase for its social responsibility, this was clearly seen in the 20142015 observation year. Whereas in 2017-2018 experienced the opposite, profitability increased and was followed by declining CSR disclosure. Things that happened in 2014-2015 or 2017-2018 are things that are not in line with theory(Fahmi, 2019) which states that with high profits, management will make extensive disclosures by providing information on social and environmental disclosures because it greatly affects the company's position and the compensation or risk received.

\section{IMPLEMENTATION METHOD}

This study uses a quantitative approach, namely research conducted with experiments and surveys, according to (Sugiyono, 2016) a quantitative approach is a data analysis method that uses numbers that will later be used to make a decision in solving problems and the data obtained analyzed using generally accepted theories. and in this study, researchers conducted direct research on data obtained from the Indonesia Stock Exchange, especially the automotive sector in 2015 to 2019.

Population and sample as two related things. According to (Sugiyono, 2014) population is a generalization area consisting of objects/subjects that have certain qualities and characteristics set by researchers to study and draw conclusions. The population used in this study are automotive companies listed on the IDX.

Table 2 Research Sample

\begin{tabular}{ll}
\hline No & Company name \\
\hline 1. & PT. Astra International, Tbk \\
\hline 2. & PT. Astra Otoparts, Tbk \\
\hline 3. & PT. Gajah Tunggal, Tbk \\
\hline 4. & PT. Mitra Pinasthika Mustika, Tbk \\
\hline 5. & PT. Multistrada Directions Sarana, Tbk \\
\hline 6. & PT. Congratulations Perfect, Tbk \\
\hline
\end{tabular}

This research is a quantitative research, and the data analysis technique used is clear, namely to answer the problem formulation or test the hypothesis that has been formulated. Then the data analysis technique uses statistical methods, the following are data analysis techniques that will be carried out by researchers in testing existing data between the dependent variable and the independent variable. 


\section{RESULTS AND DISCUSSION}

\subsection{Research result}

\subsubsection{Classic assumption test}

The classical assumption test used in this study includes normality test, multicollinearity test, autocorrelation test, and heteroscedasticity test.

\subsubsection{Normality Test}

Normality test is a basic prerequisite in parametric analysis, because the data used must be normally distributed. Normality testing can be done using SPSS16 in processing data, one of which is the One-Sample Kolmogrov-Smirnov Test. Data is declared normally distributed if it is significantly greater than 0.05 .

To support the statement that the data is normally distributed, the test is completed with statistical test tests using the Kolmogorv Smirnov test, which is presented below:

Table 3 Data Normality Test Results

One-Sample Kolmogorov-Smirnov Test

\begin{tabular}{lll}
\hline & & $\begin{array}{l}\text { Unstandardized } \\
\text { Residual }\end{array}$ \\
\hline $\mathrm{N}$ & & 30 \\
Normal Parameters & mean & .0000000 \\
& Std. Deviation & $5.66646027 \mathrm{E} 8$ \\
Most Extreme Differences & Absolute & 0.173 \\
& Positive & 0.173 \\
& negative & -0.130 \\
Kolmogorov-Smirnov Z & & 0.950 \\
asymp. Sig. (2-tailed) & & 0.328 \\
\hline
\end{tabular}

Based on table 4.6, the output of SPP shows that the value of sig (2-tailed) is $0.328>0.05$, so it can be concluded that the entire sample used in this study came from a normally distributed population.

\subsubsection{Multicollinearity Test}

Multicollinearity test aims to test whether the regression model found a correlation between the independent variables. If there is a correlation then there is a multicollinearity problem so that the regression model cannot be used. Detecting the presence or absence of multicollinearity symptoms is by looking at the tolerance and variance inflation factor (VIF) values, as well as analyzing the correlation matrix of the independent variables. The level of multicollinearity that can still be tolerated, namely: Tolerance $>0.10$, and VIF value $<5$. The following table presents the results of the multicollinearity test:

Table 4 Multicollinearity Test Results

\begin{tabular}{llll}
\hline \multicolumn{3}{c}{ Coefficientsa } \\
\cline { 3 - 4 } & \multicolumn{1}{c}{ Model } & \multicolumn{2}{c}{ Collinearity Statistics } \\
\cline { 2 - 4 } X1 & Company Size & 0.43054132 & VIF \\
\hline X2 & Board of Commissioners Size & 0.3775661 & 2.322657 \\
\hline X3 & Profitability & 0.74317504 & 1.345543 \\
\hline
\end{tabular}


Based on table 4.7. Above, it can be concluded that there is no multicollinearity between the independent variables which is indicated by the tolerance value of each variable greater than 0.1 . Tolerance value $\mathrm{X} 1=0.430 \mathrm{X} 2=0.377 \mathrm{X} 3=0.743$. The VIF value of each independent variable is also smaller than 5 .

\subsubsection{Heteroscedasticity Test}

Heteroscedasticity test aims to determine whether in the regression model there is an inequality of variance from the residuals of one observation to another observation. Because to see if there is an inequality of variance from the residuals of one observation to another observation. The regression model that meets the requirements is where the variance of the residuals from one observation to another observation remains constant or is called homoscedasticity. A good regression model is that there is no heteroscedasticity. There are several ways to test whether there is a heteroscedasticity situation in the error term variance for the regression model.

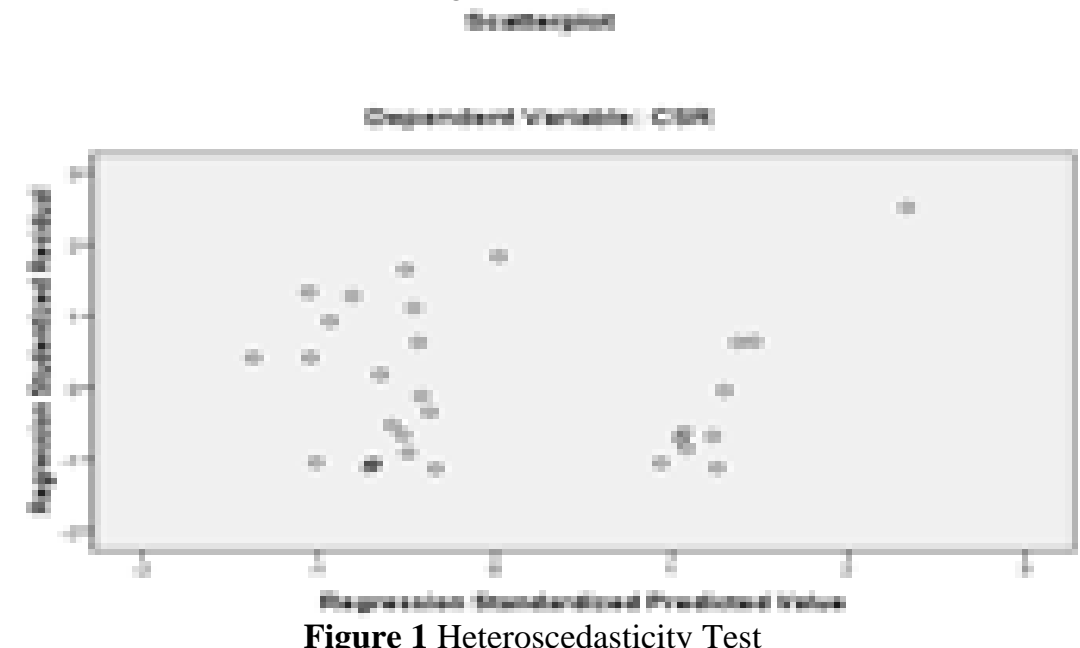

\subsubsection{Autocorrelation Test}

The autocorrelation test aims to see whether there is a correlation between a period $t$ and the previous period. Autocorrelation generally occurs in time series data. If the DW value lies between du and $(4-\mathrm{du})$ or $\mathrm{du}<$ with DW < with $(4-\mathrm{du})$. It means that it is free from autocorrelation. If the DW value is less than $\mathrm{dL}$ or DW is greater than $(4-\mathrm{dL})$ it means that there is autocorrelation.

Table 5 Autoacceleration Test Results Model Summaryb

\begin{tabular}{lrrrr}
\hline Model & $\mathrm{R}$ & $\mathrm{R}$ Square & Adjusted R Square & Std. Error of the Estimate \\
\hline 1 & $0.106 \mathrm{a}$ & 0.011 & -0.103 & 5.984E8 \\
\hline $\begin{array}{l}\text { Predictors: (Constant), Profitability, Company Size, Board of Commissioners Size } \\
\text { Dependent Variable: CSR }\end{array}$
\end{tabular}

From the table above, it is known that the $\mathrm{R}$ value is 0.106 . This shows that the correlation between CSR and its three independent variables is strong $(>0.5)$. The value of RSquare I (Coefficient of determination) is 0.011 . However, because the number of independent variables is more than two, Adjusted R Square is used, which is -0.103 . This means that $-10.3 \%$ of the variation of VAT receipts is explained by the independent variables, namely company size, board of commissioners size and profitability. While the rest $(100 \%-10.3 \%=89.7 \%)$ is explained by the variables. 


\subsubsection{Hypothesis Test}

\subsubsection{Partial Significance Test (t Test)}

The t-test was used to test the significance of the constant and each independent variable. Based on the results of processing SPSS version 16, the following results were obtained:

Table $6 \mathrm{t}$ test results Coefficientsa

\begin{tabular}{|c|c|c|c|c|c|c|}
\hline \multirow[b]{2}{*}{ Model } & \multicolumn{3}{|c|}{ Unstandardized Coefficients } & \multirow{2}{*}{$\begin{array}{l}\text { Standardized } \\
\text { Coefficients } \\
\text { Beta }\end{array}$} & \multirow[t]{2}{*}{$\mathrm{t}$} & \multirow[t]{2}{*}{ Sig } \\
\hline & B & & td. Error & & & \\
\hline 1 (Constant) & $5.941 \mathrm{E} 8$ & $4.330 \mathrm{E} 8$ & & & 1.372 & .182 \\
\hline$(\mathrm{x} 1)$ & 0.259 & 1,678 & .046 & & .154 & .879 \\
\hline$(\mathrm{x} 2)$ & 3.463E6 & $6.268 \mathrm{E} 7$ & .018 & & .055 & .956 \\
\hline (x3) & $5.835 \mathrm{E} 6$ & $1.422 \mathrm{E} 7$ & .093 & & .410 & .685 \\
\hline
\end{tabular}

Based on the results of the multiple linear regression test above, the regression equation model in this study is as follows:

$$
C S R=5,941+0,259+3,463+5,835+e
$$

How to make decisions can be done by comparing the value of probability or sig. With a significance level value, that is, if the value is $5 \%$, the value of the partial regression coefficient $=0$. This means that the influence between the independent variables on the CSR variable is not statistically significant at the 5\% significant level. However, if the probability value $<$ the significant level is used, then the value partial regression coefficient 0 . This means that the effect of the independent variables on the VAT revenue variable is statistically significant at a significant level of $5 \%$.

Based on table 5.5 above in the multiple regression equation, the relationship of each independent variable to the disclosure of corporate social responsibility can be interpreted as follows: 1. The constant value (b0) of 5.941 means that if there is no firm size (X1), board of commissioners size (X2), and profitability (X3), the corporate social responsibility (Y) disclosure index will increase by 5.941 .

2. The regression coefficient b1 is 0.259 , meaning that any increase in the other independent variables is considered zero. This shows that there is a positive relationship between company size and corporate social responsibility disclosure, meaning that each company size increases, the value and cost of corporate social responsibility disclosure activities will increase and vice versa.

3. The regression coefficient b2 is 3.463 , meaning that any increase in the other independent variables is considered zero. This shows that there is a positive relationship between the size of the board of commissioners and the disclosure of corporate social responsibility, meaning that each time the size of the board of commissioners increases, the value and cost of corporate social responsibility disclosure activities will increase and vice versa.

4. The regression coefficient $b 3$ of 5.835 means that the increase in other independent variables is considered zero. This shows that there is a positive relationship between profitability and corporate social responsibility disclosure, meaning that every time profitability increases, the value and cost of corporate social responsibility disclosure activities will increase and vice versa.

From table 5.5 above, the effect of each independent variable on the dependent variable is explained as follows:

1. The firm size variable has a tcount value of $0.154<$ ttable 1.697 with a significant level $(0.879)$ $>(0.05)$. It can be concluded that firm size does not partially affect the disclosure of corporate 
social responsibility. so that the proposed hypothesis is that the size of the company affects the disclosure of corporate social responsibility is rejected.

2. The variable size of the board of commissioners has a value of tcount $0.055<$ ttable 1.697 with a significant level $(0.956)>(0.05)$ it can be concluded that the size of the board of commissioners does not partially affect the disclosure of corporate social responsibility. so that the proposed hypothesis is that the size of the board of commissioners affects the disclosure of corporate social responsibility is rejected.

3. The profitability variable has a value of tcount $0.410<$ ttable 1.697 with a significant level $(0.685)$ $>(0.05)$. It can be concluded that profitability does not partially affect the disclosure of corporate social responsibility. so that the proposed hypothesis that profitability affects the disclosure of corporate social responsibility is rejected.

\subsubsection{Simultaneous Significance Test (F Test)}

To see the effect of firm size, board size and profitability on CSR simultaneously can be calculated using the F test. Based on the results of data processing with the SPSS 16 program, the following results were obtained:

Table 7 Test Results f ANOVAb

\begin{tabular}{|c|c|c|c|c|c|c|}
\hline \multicolumn{2}{|c|}{ Model } & \multirow{2}{*}{$\frac{\text { Sum of Squares }}{1.048 \mathrm{E} 17}$} & \multirow{2}{*}{$\frac{\mathrm{df}}{3}$} & \multirow{2}{*}{$\frac{\text { Mean Square }}{3.495 \mathrm{E} 16}$} & \multirow{2}{*}{$\frac{F}{0.098}$} & \multirow{2}{*}{$\frac{\text { Sig. }}{0.961 \mathrm{a}}$} \\
\hline 1 & Regression & & & & & \\
\hline & Residual & $9.312 \mathrm{E} 18$ & 26 & $3.581 \mathrm{E} 17$ & & \\
\hline & Total & $9.416 \mathrm{E} 18$ & 29 & & & \\
\hline
\end{tabular}

a. Predictors: (Constant), Profitability, Company Size, Board of Commissioners Size b. Dependent Variable: CSR

Based on table 5.6 above, if using a significant level of $=5 \%$, it can be compared that significant $<$ or $<0.05$. The test results in table 5.6 show that the Fcount value is $0.098<$ Ftable 1.84 or a significant value is $0.961>0.05$. The results of this study conclude that firm size, board of commissioners size, and profitability simultaneously have no significant effect on CSR.

\subsubsection{Coefficient of Determination (R2)}

The value of the correlation coefficient $(\mathrm{R})$ shows how big the correlation or relationship between the independent variables and the dependent variable:

Table 8 Coefficient of Determination Test Results

Model Summaryb

\begin{tabular}{|c|c|c|c|c|}
\hline $\begin{array}{l}\text { Mode } \\
1\end{array}$ & $\mathrm{R}$ & R Square & Adjusted R Square & Std. Error of the Estimate \\
\hline 1 & $0.106 a$ & 0.011 & -0.103 & $5.984 \mathrm{E} 8$ \\
\hline
\end{tabular}

From the table above, it is known that the $\mathrm{R} 2$ value is 0.106 or $10.6 \%$, meaning that the relationship between the independent variables, namely company size, board of commissioners, and profitability on the dependent variable, namely corporate social responsibility disclosure is $10.6 \%$. The figure of $10.6 \%$ indicates that the independent variables together have a fairly strong relationship with the disclosure of corporate social responsibility. 
The adjusted $\mathrm{R}$ Square value is -0.103 or $-10.3 \%$, meaning that $-10.3 \%$ the $\mathrm{Y}$ variable (disclosure of corporate social responsibility) is influenced by the variables of company size, board of commissioners size, and profitability. While the remaining $89.7 \%$ is influenced by other variables not included in this study such as the type of leverage, foreign ownership, industry type and others.

\subsection{Discussion}

\subsubsection{Partial Effect of Firm Size on Corporate Social Responsibility Disclosure}

From the results of the study, it is known that the size of the company partially does not have a significant effect on the disclosure of corporate social responsibility. and it is concluded that large company size (total assets) is not an incentive for companies to disclose the costs of CSR activities. according to(Fahmi, 2019)A company that has a large company size is not a guarantee that the company will carry out its social responsibilities. From the results of the sample company, only a few companies disclose the costs of CSR activities in accordance with their CSR activities.

In addition, the research results are in accordance with the legitimacy theory which states that companies will try to comply with the rules and norms contained in society, including Law no. 40 of 2007 so that the company's existence can be accepted in the community. With the existence of this law, it also creates a climate for implementing CSR activities for all public companies that are mandatory and no longer voluntary so that the size of the company is thought to be less relevant to the disclosure of corporate social responsibility.

The results of this study are supported by previous research conducted (Susilowati et al., 2018), (Fahmi, 2019) with the results of the study showing that partially the size of the company has no significant effect on the disclosure of corporate social responsibility.

\subsubsection{Partial Influence of Board of Commissioners Size on Corporate Social Responsibility Disclosure}

From the results of the study, it is known that the size of the board of commissioners partially has no significant effect on the disclosure of corporate social responsibility. and it can be concluded that the board of commissioners does not monitor its management in Corporate Social Responsibility Disclosures in the company's annual report. according to(Fahmi, 2019)The board of commissioners considers that not disclosing CSR will not harm the company. Therefore, it is necessary to carry out more supervision of the company's management so that each company carries out its social responsibility. On the other hand, if the company carries out corporate social disclosures, the company will get many benefits, such as getting a good positive influence in the eyes of the community around the company, besides that the company will also be able to maintain and obtain quality human resources.

Factors that also affect the failure of the results of this study is the effectiveness of the performance of the board of directors, so that regardless of the number of members of the board of directors will not affect the performance of management if the performance is less effective. More and more members of the board of directors bring benefits to the company in managing resources. The results of this study are supported by previous research conducted,(Fahmi, 2019), (Nufriyanto Arif Fauzi and Hanny Y Rahmawati, 2016) with research results showing that partially the size of the board of commissioners has no significant effect on the disclosure of corporate social responsibility.

\subsubsection{The effect of profitability partially on the Disclosure of Corporate Social Responsibility}

From the results of the study, it is known that partially profitability has no significant effect on the disclosure of corporate social responsibility. although Return on Assets is one of the factors that encourage management to disclose Corporate Social Responsibility in the company's annual report. according to(Fahmi, 2019)This is because Return On Assets does not guarantee that a high profit will reveal a large CSR as well. Because from the research sample, there are several companies 
that get a fairly low Return On Assets in several periods, but on the contrary reveal social responsibility and the costs are quite large.

From the theory that when a company has a high level of profit, the company (management) considers it necessary to do things that can inform the company's financial success. On the other hand, when the level of profitability is high, they expect users of the report to read the company's performance when carrying out social and environmental activities carried out by the company. The results of this study are supported by the theory which states that with high profits, management will make extensive disclosures by providing information on social and environmental disclosures because it greatly affects the company's position and compensation or risks received.

The results of this study are supported by previous research conducted, (Susilowati et al., 2018), (Nufriyanto Arif Fauzi and Hanny Y Rahmawati, 2016) with the results of the study showing that partially profitability has no significant effect on the disclosure of corporate social responsibility.

\subsubsection{Discussion of Simultaneous Significance Test Results}

From the results of hypothesis testing, it is found that simultaneously the variables of company size, ROA and the size of the board of commissioners have no significant effect on Disclosure of Corporate Social Responsibility in automotive companies. This can be seen from the Fcount value of 0.098 which is greater than Ftable of 1.48 or a significant value of 0.961 which is smaller than 0.05 . Based on these results, it can be concluded that the variables of firm size, ROA and the size of the board of commissioners simultaneously have no significant effect on Corporate Social Responsibility Disclosure in automotive companies.

The magnitude of the influence of the independent variable on the dependent variable is indicated by the Adjusted R square value of -0.103 or equal to $-10.3 \%$. This is because although the size of the company, ROA and the size of the board of commissioners are one of the benchmarks for CSR disclosure, there are still many other variables not included in this study which are thought to affect the CSR disclosure of automotive companies.

\subsubsection{Discussion of the Results of the Coefficient of Determination}

From the results of the coefficient of determination test in table 4.11, it is known that the $\mathrm{R}$ value is -0.103 or $-10.3 \%$ which indicates the ability of company size, board of commissioners, and profitability to disclosure of corporate social responsibility is $-10.3 \%$. The figure of $-10.3 \%$ indicates that the independent variables together have a fairly strong relationship with the disclosure of corporate social responsibility.

While the remaining $89.7 \%$ is influenced by other variables not included in this study. This value indicates that the size of the company, the size of the board of commissioners, and profitability in explaining the disclosure of corporate social responsibility in the future is relatively small, because the effect is small, which is less than 50\%. While the other variables included in this study were larger.

\section{CONCLUSION}

The main objective of this study is to determine the effect of company size, size of the board of commissioners, and profitability on the disclosure of corporate social responsibility. Based on the results of data analysis, hypothesis testing and discussion, it can be concluded from this research as follows:

1. Partially, the size of the company has a positive effect, but does not have a significant effect on Disclosure of Corporate Social Responsibility in automotive companies.

2. Partially, profitability has a positive effect, but has no significant effect on Corporate Social Responsibility Disclosure in automotive companies.

3. Partially, the size of the Board of Commissioners has a positive effect, but does not significantly affect the Disclosure of Corporate Social Responsibility in automotive companies. 
4. Simultaneously shows that Company Size, Profitability and Size of the Board of Commissioners have no significant effect on Corporate Social Responsibility in automotive companies.

\section{REFERENCES}

Barton, sidney L., Ned C, Hill dan Sirnivasan Alpi, M. F. (2016). Pengaruh Return On Assets Dan Earning Per Share Terhadap Harga Saham Pada Perusahaan Tekstil Dan Garment Yang Terdaftar Di Bursa Efek Indonesia. Jurnal Ilmiah Maksitek, 1(1), 56-64.

Alpi, M. F. (2018). Pengaruh Current Ratio Dan Total Assets Turnover Terhadap Return On Assets Pada Perusahaan Plastik Dan Kemasan. Jurnal Riset Akuntansi Aksioma, 17(2), 1-36.

Astuti, D. . (2019). Pengaruh Profitabilitas, Leverage, Dan Ukuran Perusahaanterhadap Luas Pengungkapantanggung Jawab Sosial. Jurnal Akuntansi Dewantara, 3(2), 179-191.

Chen, M. (2019). Pengaruh Ukuran Dewan Komisaris Dan Kepemilikan Asing Terhadap Luas Pengungkapan Csr. El Muhasaba Jurnal Akuntansi, 10, No.2, 141-158.

Fahmi, M. (2019). Pengaruh Karakteristik Perusahaan Terhadap Pengungkapan Corporate Social Responsibility Pada Perusahaan Consumer Goods Yang Terdaftar Di Bursa Efek Indonesia. Jurnal Riset Akuntansi Dan Bisnis, 19(1), 26-39.

Hani, S. (2012). Pengaruh Karakteristik Perusahaan Dan Corporate Governance Terhadap Pemilihan Akuntansi Konservatif. Jurnal Riset Akuntansi Dan Bisnis, 12(1), 1-16.

Hanum, Z. (2015). Pengaruh Profitabilitas Terhadap Modal Kerja Pada Perusahaan Makanan Dan Minuman Yang Terdaftar Di Bursa Efek Indonesia. Jurnal Manajemen Dan Bisnis, 1(2), 126 135.

Majied Sumatrani Saragih, M. . (2021). STRATEGIES FOR USING PROFIT AND CASH FLOW STATEMENTS IN ASSESSING THE FINANCIAL PERFORMANCE OF PRIVATE BANK COMPANIES ON THE INDONESIA STOCK EXCHANGE. International Journal of Economic, Business, Accounting, Agriculture Management and Sharia Administration (IJEBAS), 1(1), 14-23. https://doi.org/10.54443/ijebas.v1i1.2

Nur Ilham, R. ., Arliansyah, A., Juanda, R., Multazam, M. ., \& Saifanur, A. . (2021). RELATHIONSIP BETWEEN MONEY VELOCITY AND INFLATION TO INCREASING STOCK INVESTMENT RETURN: EFFECTIVE STRATEGIC BY JAKARTA AUTOMATED TRADING SYSTEM NEXT GENERATION (JATS-NG) PLATFORM. International Journal of Economic, Business, Accounting, Agriculture Management and Sharia Administration (IJEBAS), 1(1), 87-92. https://doi.org/10.54443/ijebas.v1i1.27

Purnasiwi, J. (2019). Analisis Pengaruh Size, Profitabilitas Dan Leverage Terhadap Pengungkapan Csr Pada Perusahaan Yang Terdaftar Di Bursa Efek Indonesia. Journal Of Chemical Information And Modeling. Https://Doi.Org/10.1017/Cbo9781107415324.004

Putri, E. I., \& Gunawan, B. (2018). Analisis Pengaruh Karakteristik Perusahaan, Ukuran Dewan Komisaris, Dan Struktur Kepemilikan Terhadap Pengungkapan Corporate Social Responsibility Di Perusahaan Property Dan Real Estate. Seminar Nasional Dan The 6th Call For Syariah Paper, 388-406.

Rofiqkoh, E., \& Priyadi, M. P. (2016). Pengaruh Profitabilitas, Leverage, Dan Ukuran Perusahaan Terhadap Pengungkapan Tanggung Jawab Sosial Perusahaan. Jurnal Ilmu Dan Riset Akuntansi Issn: 2460-0585, 5, No.10.

Santioso, L., \& Chandra, E. (2012). Pengaruh Profitabilitas, Ukuran Perusahaan, Leverage, Umur Perusahaan, Dan Dewan Komisaris Independen Dalam Pengungkapan Corporate Social Responsibility. Jurnal Bisnis Dan Akuntansi,14,No.1(April),17-30.

Suriana, S. (2021). THE INFLUENCE OF ACCOUNTABILITY AND TRANSPARENCY OF FINANCIAL MANAGEMENT OF VILLAGE FUNDS ON VILLAGE GOVERNMENT PERFORMANCE IN KOTARIH BARU VILLAGE KOTARIH DISTRICT SERGAI 
REGENCY. International Journal of Educational Review, Law And Social Sciences (IJERLAS), 1(1), 53-66. https://doi.org/10.54443/ijerlas.v1i1.30

Susilowati, F., Wafirotin, K. Z., \& Hartono, A. (2018). Pengaruh Ukuran Perusahaan, Profitabilitas, Leverage, Tipe Industri, Dan Ukuran Dewan Komisaris Terhadap Corporate Social Responsibility Disclosure (Studi Empiris Pada Perusahaan Sektor Industri Barang Konsumsi Yang Terdaftar Di Bursa Efek Indonesia Perio. Isoquant : Jurnal Ekonomi, Manajemen Dan Akuntansi. Https://Doi.Org/10.24269/Iso.V2i2.186

Yuliana, R., Purnomosidhi, B., \& Sukoharsono, E. G. (2008). Pengaruh Karakteristik Perusahaan Terhadap Pengungkapan Corporate Social Responsibility (Csr) Dan Dampaknya Terhadap Reaksi Investor. Jurnal Akuntansi Dan Keuangan Indonesia. 